\title{
Therapeutic Alternatives for the Treatment of Infected Pancreatic Necrosis. An Overview
}

\author{
Alternativas Terapéuticas para el Tratamiento de la \\ Necrosis Pancreática Infecciosa. Una Visión General
}

Carlos Manterola ${ }^{*, * * * * * ;}$; Sebastián Urrutia* \& Franz Apodaca*****

MANTEROLA, C.; URRUTIA, S. \& APODACA, F. Therapeutic alternatives for the treatment of infected pancreatic necrosis. An overview. Int. J. Morphol., 32(4):1357-1364, 2014.

SUMMARY: Despite diagnostic and therapeutic advances, the treatment of infected pancreatic necrosis (IPN) continues to be a complex problem to solve. The aim of this study is to evaluate the effectiveness of different surgical alternatives for the treatment of IPN. Articles published between 2000 to 2013, and related to effectiveness of open surgery (OS) and minimally invasive treatmente (MIT) in patients with IPN were evaluated. PubMed, MEDLINE, The Cochrane Database of Systematic Reviews, Cochrane Central Register RCT, DARE, IBECS, SciELO, LILACS, PAHO, WHOLIS, ASERNIP-S, NIHR, HTA, Clinical Excellence, York Health Economic Consortium and Tripdatabase were reviewed, searching systematic reviews (SR), randomized clinical trials (RCT) and observational studies (OST), in which the effectiveness of OS and MIT was evaluated in relation to the variables mortality, intra-abdominal bleeding, development of enterocutaneous fistula or hollow viscera perforation, development of pancreatic fistula, reoperations for complications, reoperations for new necrosectomy, development of diabetes mellitus and pancreatic enzyme requirements. Three hundred eighty-nine articles were retrieved, 10 of which met the selection criteria (2 SR, 1 RCT and 7 OST). The studies have a level of evidence of 2a, 2b, 3a and 4. MIT are associated with better results than OS in all variables analyzed, but significantly only in the development of diabetes mellitus and pancreatic enzyme requirement. Articles found are few and heterogeneous, making meaningful conclusions difficult. Studies with a better level of evidence, methodological quality and population size are needed to make conclusions and recommendations.

KEY WORDS: "Pancreatitis, Acute Necrotizing/complications"; "Pancreatitis, Acute Necrotizing/therapy"; Infected pancreatic necrosis; Necrosectomy; Evidence-based medicine; Overview.

\section{INTRODUCTION}

Acute pancreatitis is an inflammatory process of varying severity, from slight and self-limiting forms with interstitial edema, to severe forms with pancreatic necrosis and extensive bleeding (Al Mofleh, 2008). Pancreatic necrosis, associated with septic conditions, determines the production of so-called infected pancreatic necrosis (IPN), a leading cause of death (Khanna et al., 2013) which can yield figures of $45 \%$ (Alsfasser et al., 2012).

Despite aggressive multiple organ support in the initial stages of the disease, patients continue to die from necrosis and septic complications, culminating in multiple organ failure, which is associated with high mortality rates (Buter et al., 2002).

Conventional treatment of IPN usually occurs in intensive care units, with nutritional support, antimicrobials, vasoactive drugs and surgery (Donald et al., 2012) based on sessions of necrosectomy by laparotomy or lumbotomy, associated with irrigation and continuous washing of the retroperitoneum, and possibly with contained laparostomy or open abdomen. However, to date there is no consensus regarding the most appropriate surgical strategy for IPN (Hart \& Baron, 2013).

Evidence suggests that the treatment for IPN is surgical debridement, and that the alternative minimally invasive accesses can be used in select circumstances (Banks et al., 2006; Wysocki et al., 2010; Navaneethan et al., 2009). Contrasting evidence maintains that the laparoscopic, endoscopic and retroperitoneal accesses can reduce morbidity and mortality in these patients (Navaneethan et al.; Heinrich et al., 2006; Stem \& Matthews, 2011).

* Department of Surgery, Universidad de La Frontera, Temuco, Chile.

** Center for Biomedical Research, Universidad de Autónoma, Temuco, Chile.

*** CEMyQ (Center of Morphological and Surgical Studies), Universidad de La Frontera, Chile.

***** Disciplina de Gastroenterologia Cirúrgica - Universidade Federal de São Paulo, São Paulo, Brasil. 
In recent years, a significant number of minimally invasive techniques (MIT) have been described. In 2007 Windsor classified these procedures according to the type of technique (endoscopic, laparoscopic and nephroscopic), the access (transperitoneal, transgastric and retroperitoneal) and the synchronization of the surgery: "step-down approach" (open surgery and MIT of the complications) and "step-up approach" (minimally invasive draining technique followed by open necrosectomy) (Windsor, 2007). Furthermore, there is a guide developed by the National Institute for Clinical Evidence that merely describes the situation and notes the lack of consensus regarding the issue (Dillon, 2011).

The aim of this study is to assess the effectiveness of the different surgical alternatives for the treatment of IPN.

\section{MATERIAL AND METHOD}

Design: Overview of the available evidence.

Population: Articles that evaluated surgical techniques to treat IPN in the population over 18 years of age, published between 2000 and 2013 in English, Spanish, French, Italian, Portuguese and German.

Inclusion criteria: Systematic reviews (SR), randomized clinical trials (RCT) and observational studies (OST: cohort studies, cases and controls, and other types of comparative studies).

Exclusion criteria: Articles with no information in terms of the type of necrosis that affected the patients in the study were excluded. Also excluded were those studies included in SR selected for analysis.

Search strategy: The search was conducted according to PICoR components: population of interest (p), intervention to be evaluated (i), the comparator for the intervention being studied (Co), and the variable result measured from the intervention (R). Using this strategy, studies were sought regarding subjects with IPN (p), those where conventional surgery was performed (I), that were compared with MIT (Co), and whose response variables would be: mortality, systemic complications, local, etc. (R). To do this, the following databases were reviewed: PubMed, MEDLINE, The Cochrane Database of Systematic Reviews, Cochrane Central Register RCT, DARE, IBECS, SciELO, LILACS, PAHO, WHOLIS, ASERNIP-S, NIHR, HTA, Clinical Excellence, York Health Economic Consortium and TRIPdatabase. Sensitive searches were conducted using
MeSH terms, free words and the Boolean connectors AND and OR, using strategies adapted for each database.

Thus, the following commands were generated: For PubMed "Pancreatitis, Acute Necrotizing" OR "Pancreatitis, Acute Necrotizing/surgery"[Mesh] OR "Pancreatitis, Acute Necrotizing/therapy"[Mesh] OR "infected pancreatic necrosis" with the limits: Clinical Trial, Controlled Clinical Trial, Review, Meta-Analysis, Systematic Reviews, Randomized Controlled Trial, Publication date from 2000/01/01 to 2013/ 12/31, Humans, Adult: 19+ years. For MEDLINE, The Cochrane Database of Systematic Reviews, Cochrane Central Register RCT, DARE, IBECS, SciELO, LILACS, PAHO, WHOLIS searches were done through the BVS using the strategy (tw:(Pancreatitis Aguda Necrotizante)) "(tw:(necrosis pancreatica)) OR (tw:(pancreatic necrosis)) AND (tw:(infected)) OR (tw:(infectada))" with the filters: Collection: International databases, Cochrane Library, national databases. Databank: MEDLINE, LILACS, IBECS (España), CENTRAL-Register of controlled clinical trials, DAREEvaluated systematic reviews, NHS-EED Economic evaluations. Type of study: Controlled Clinical Trial, Cohort Study, Evaluated Systematic Reviews, Case and Control Studies, Overview. Clinical aspect: Therapy. Limit: Humans, Adult. Type of document: Article. And the databases ASERNIP-S, NIHR, HTA, Clinical Excellence, York Health Economic Consortium, through TRIPdatabase suing the strategy "(Infected pancreatic necrosis) (Surgery) (minimally invasive treatment) (morbidity)".

Synthesis and evaluation of the evidence: This began with an evaluation of the internal validity of the studies, for which summary tables were created using the CEBM format. The Jadad Scale for RCT (Jadad et al., 1996; Roa, 2008) and validity tables were constructed (using the design proposed by SIGN) (Scottish Intercollegiate Guidelines Network, 2014). Then, a classification was made of levels of evidence, using the system proposed by CEBM(Centre for Evidence-based Medicine at the University of Oxford, 2009). Finally, an overall classification of the evidence was made for each intervention, grouped into hhigh, moderate and low, applying a modified approach of the GRADE system, which includes the study design, the internal validity, the coherence, the accuracy of the results, the publication bias and whether the evaluation of the evidence is direct or indirect (Guyatt et al., 2006).

Measurement variables: Effectiveness of open surgery (OS) vs. MIT with respect to the variables mortality, intra-abdominal bleeding, development of enterocutaneous fistula or hollow viscera perforation, development of pancreatic fistula, reoperation due to complications, reoperation for new necrosectomy, development of diabetes mellitus and pancreatic enzyme requirements. 
Plan of analysis: The selected data were collected in a Windows Excel spreadsheet. Then, the information from each article was analyzed, extracting the data of interest.

Ethical Aspects: During the analysis of the selected articles, the authors and centers where the studies originated were masked to further reduce selection and analysis bias.

Funding: Medical Sciences Ph.D. program. Universidad de La Frontera, Chile.

\section{RESULTS}

Three hundred eighty-nine records were recovered, 10 of which fulfilled the selection criteria: 2 SR, 1 RCT and 7 OS (Bakker et al., 2012; Bausch et al., 2012; Boland et al., 2010; Cirocchi et al., 2013; Connor et al., 2005; Guo et al., 2013; Horvath et al., 2010; Senthil Kumar et al., 2012; Tan et al., 2012; van Baal et al., 2011). The flow chart of the selected articles is detailed in Figure 1.

The results reported below are based on data from a total population of 25 studies (10 articles already defined and 15 included in the two SR (van Baal et al.; Freeny et al., 1998; Gambiez et al., 1998; Fotoohi et al., 1999; Baril et al., 2000; Cheung et al., 2005; Navalho et al., 2006; Lee et al., 2007; Bruennler et al., 2008; Mortelé et al., 2009; Rocha et al., 2009; van Santvoort et al., 2010; Raraty et al., 2010) [two of which are repeated in the two SR (Gambiez et al.; van Santvoort et al.)]), and 1461 subjects operated on for IPN: 896 with MIT and 565 with OS.

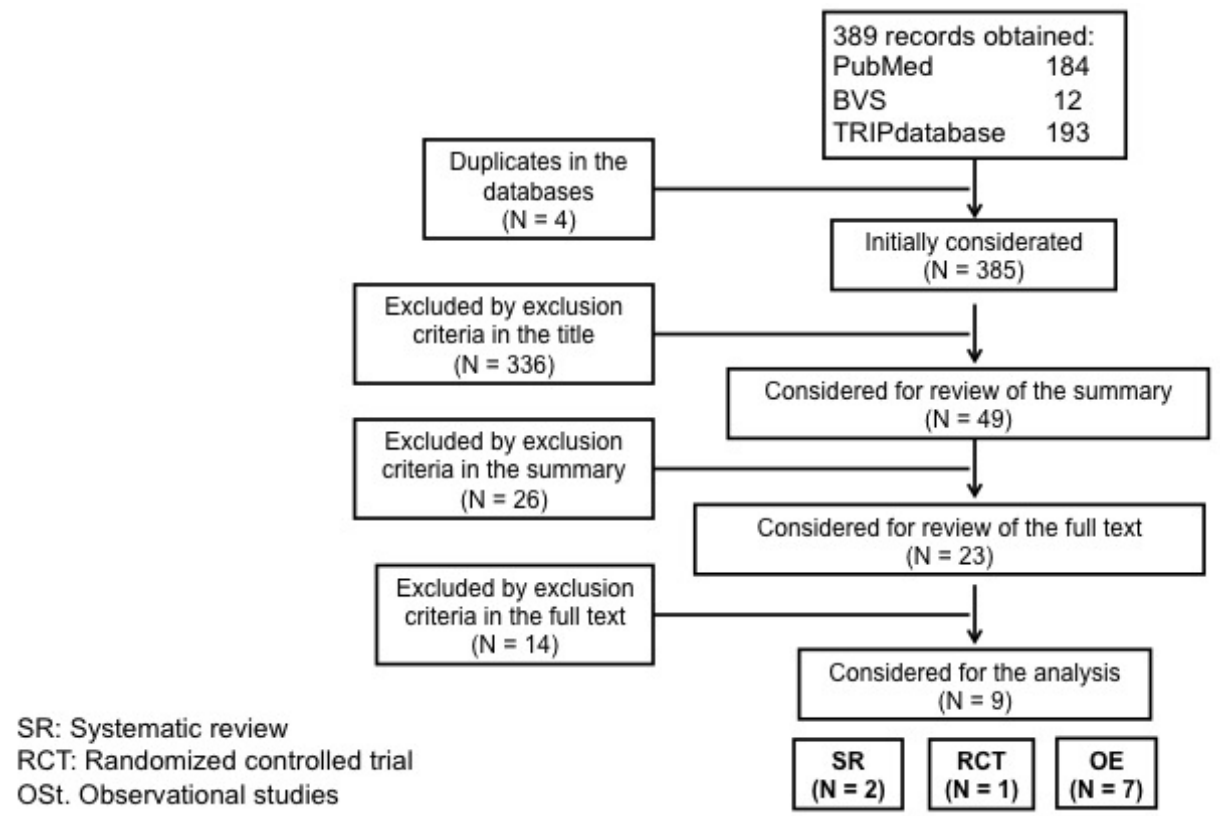

Fig. 1. Flow chart of the search results according to the strategies described.

Table I. Summary of studies included.

\begin{tabular}{|c|c|c|c|c|}
\hline Authors & Year of publication & Type of study & $n$ of cases included & Level of evidence \\
\hline Bakker et al. & 2012 & $\mathrm{RCT}$ & 20 & $2 b$ \\
\hline Bausch et al. & 2012 & OST & 50 & 4 \\
\hline Boland et al. & 2010 & OST & 21 & 4 \\
\hline Cirocchi et al. & 2013 & SR & 346 & $2 \mathrm{a}$ \\
\hline Connor et al. & 2005 & OST & 88 & 4 \\
\hline Guo et al. & 2013 & OST & 412 & 4 \\
\hline Horvath et al. & 2010 & OST & 34 & 4 \\
\hline Senthil Kumar et al. & 2012 & OST & 30 & 4 \\
\hline Tan et al. & 2012 & OST & 76 & 4 \\
\hline Van Baal et al. & 2011 & $\mathrm{SR}$ & 384 & $3 a$ \\
\hline
\end{tabular}

SR: Systematic review; RCT: Randomized clinical trial; OST: Observational study 
The techniques evaluated for MIT were retroperitoneal necrosectomy $(\mathrm{RN})$, endoscopic transgastric necrosectomy (EGN), percutaneous drainage (guided by US or CT), video-assisted surgical necrosectomy (VASN) and laparoscopic necrosectomy (LN). The following details the synthesis of the findings, a summary of which can be found in Table I.

In relation to the variable "perioperative mortality", 2 SR, 1 RCT and 5 OST (treatment studies 2a, 2b, 3a and 4) were found that reported the variable. For this variable, figures ranged from $4.0 \%$ to $63.0 \%$, with the lower numbers being for the MIT. In one SR, $17.2 \%$ and $29.8 \%$ were reported for MIT and OS respectively ( $\mathrm{p}=0.06$ ); and OR of 0.43 (CI 95\% of 0.18-1.05) (Boland et al.); in a RCT where VASN was compared to EGN, lower mortality was reported for VASN ( $40.0 \%$ vs. $10.0 \%$; $\mathrm{p}=0.30$; $\mathrm{RR}=0.3$ (CI 95\% from $-0.08-0.60$ ) (Bakker et al.). Finally, in 5 OS, 63.0\%, 21.0\%, $6.0 \%$ were described for OS, RN and EGN respectively (Bausch et al.); $39.0 \%$ and $19.0 \%$ for OS and MIT ( $\mathrm{p}=0.06$ ) (Connor et al.); $20.4 \%$ and $8.3 \%$ for OS and RN respectively $(\mathrm{p}=0.004)$ (Guo et al.); $11.0 \%$ y $4.0 \%$ for percutaneous and retroperitoneal drainage (Horvath et al.); and $4.0 \%$ and $5.9 \%$ for $\mathrm{LN}$ and OS respectively $(\mathrm{p}=0.791)$ (Tan et al.) (High, moderate and low quality).

For the variable "intra-abdominal bleeding", 1 RS and 5 OST (treatment studies 2a and 4) were found that reported the variable. For this, numbers ranged from 1.9\% to $26.0 \%$, with the lower numbers being for the MIT. One SR reported $13.0 \%$ and $16.5 \%$ for MIT and OS respectively $(\mathrm{p}=0.46)$; and OR of 0.79 (CI 95\% of 0.45-1.50) (Cirocchi et al.); and in $5 \mathrm{OS}$ the following figures were described: $26.0 \%, 21.0 \%$ and $17.0 \%$ OS, RN and EGN respectively (Bausch et al.); $10.0 \%$ and $13 \%$ for OS and MIT respectively (Connor et al.); $6.3 \%$ and $1.9 \%$ for OS and RN respectively $(\mathrm{p}=0.08)$ (Guo et al.); $11.0 \%$ and $8.0 \%$ for percutaneous and retroperitoneal drainage (Horvath et al.); and $4.0 \%$ and $5.9 \%$ for MIT and OS respectively ( $\mathrm{p}=0.672)$ (Tan et al.) (High and low quality).

For the variable "development of enterocutaneous fistula or hollow viscera perforation", 1 SR, 1 RCT and 5 OST (treatment studies 2a, 2b and 4) were found that reported the variable. For this variable, numbers ranged from $1.9 \%$ to $21.4 \%$, with the lower numbers being for the MIT. In a SR, $11.7 \%$ and $21.4 \%$ were reported for MIT and OS respectively ( $\mathrm{p}=0.06$ ); and OR of 0.43 (CI 95\% of $0.30-$ 1.46) (Cirocchi et al.); in a RCT where VASN was compared to EGN, lower development of fistulae was reported for EGN (20.0\% vs. $0.0 \% ; \mathrm{p}=0.47$; RR $=0.2$ (IC 95\% of $-0.11-$ 0.51) (Bakker et al.); and 5 OS in which the following figures were reported: 0.0 and $28.0 \%$ for OS and EGN (Bausch et al.); $5.0 \%$ and $4.0 \%$ for OS and MIT (p<0.05) (Connor $e t$ $a l$. ); $9.5 \%$ and $1.9 \%$ for OS and RN (p=0.009) (Guo et al.); $44.0 \%$ and $8.0 \%$ for percutaneous and retroperitoneal drainage (Cirocchi et al.); and $5.9 \%$ and $4.0 \%$ for MIT and OS respectively ( $\mathrm{p}=0.672)$ (Tan et al.) (High, moderate and low quality).

For the variable "development of pancreatic fistula", 1 SR, 1 RCT and 2 OST (treatment studies 2a, 2b and 4) were found that reported the variable. For this variable, numbers ranged from $9.7 \%$ to $70.0 \%$ with the lower numbers being for the MIT. In a SR, 9.7\% and $18.7 \%$ are reported for MIT and OS respectively ( $\mathrm{p}=0.30$ ); and OR of 0.66 (CI 95\% of 0.30-1.46) (Cirocchi et al.); in a RCT where VASN was compared to EGN, lower development of pancreatic fistulae were reported with EGN (70.0\% vs. $10.0 \%$; $\mathrm{p}=0.02 ; \mathrm{RR}=$ 0.6 (CI 95\% of -0.17-0.81) (Bakker et al.); in 2 OS, the following figures were described: $29.6 \%$ and $47.0 \%$ for MIT and OS respectively ( $\mathrm{p}=0.002$ ) (Connor et al.); $32.0 \%$ and $54.9 \%$ for MIT and OS ( $\mathrm{p}=0.001)$ (Tan et al.) (High, moderate and low quality).

For the variable "reoperation due to postoperative complications", 1 SR and 4 OST (treatment studies 2a and 4) were found that reported the variable. For this variable, numbers ranged from $4.0 \%$ to $43.3 \%$, with the lower numbers being for the MIT. In the SR, 27.6\% and 43.3\% for MIT and OS were reported respectively $(\mathrm{p}=0.08)$; and $\mathrm{OR}$ of 0.50 (CI 95\% of 0.23-1.08) (Cirocchi et al.). In one OS, 5.9\% and $4.0 \%$ were described for MIT and OS respectively, with a value of $\mathrm{p}=0.63$ (Tan et al.) (High and low quality).

For the variable "reoperation for necrosectomy", 1 SR, 1 RCT and 2 OST (treatment studies 2a, 2b, 3a and 4) were found that reported the variable. For this variable, numbers ranged from $21.0 \%$ to $96.7 \%$, with the lower numbers being for the MIT. In one SR, $63.7 \%$ and $96.7 \%$ were reported for MIT and OS respectively $(\mathrm{p}=0.19)$; and OR of 0.16 (CI 95\% of 0.00-3.07) (Cirocchi et al.); in a RCT where VASN was compared to EGN, a lower number of reoperations for necrosectomy was reported with EGN (3 vs. 1; $\mathrm{p}=0.007$ ) (Bakker et al.). In 2 OS the following figures were described: $21.0 \%$ and $28.0 \%$ for RN and EGN respectively ( $\mathrm{p}=0.002$ ) (Bausch et al.); $26.6 \%$ and $46.6 \%$ for RN and OS ( $\mathrm{p}=0.366)$ (Senthil Kumar et al.) (High, moderate and low quality).

For the variable "development of diabetes mellitus", 1 RS and 1 RCT (treatment studies $2 \mathrm{a}$ and $2 \mathrm{~b}$ ) were found that reported the variable. For this variable, numbers ranged from $16.0 \%$ to $38.0 \%$ with the lower numbers being for the MIT. In the SR, $16.0 \%$ and $38.0 \%$ were reported for MIT and OS respectively ( $\mathrm{p}=0.03$ ); and OR of 0.32 (CI 95\% of 




Fig. 2. Diagram of the distribution of studies, patients and surgical techniques used for the treatment of IPN.

Table II. Summary of evidence.

\begin{tabular}{|c|c|c|c|}
\hline Study variables & n of studies & Quality of evidence & Summary of findings \\
\hline Perioperative mortality & $\begin{array}{l}2 \mathrm{SR} \\
5 \mathrm{OST}\end{array}$ & High and low & Lower mortality with MIT \\
\hline & $1 \mathrm{RCT}$ & Moderate & Lower mortality with VASN than with EGN \\
\hline Intra-abdominal bleeding & $\begin{array}{l}1 \mathrm{SR} \\
5 \mathrm{OST}\end{array}$ & High and Low & Lower mortality with MIT \\
\hline $\begin{array}{l}\text { Enterocutaneous fistula or } \\
\text { hollow viscera perforation }\end{array}$ & $\begin{array}{l}1 \mathrm{SR} \\
5 \mathrm{OST}\end{array}$ & High and low & Lower frequency with MIT \\
\hline \multirow{3}{*}{ Pancreatic fistula } & $1 \mathrm{RCT}$ & Moderate & Lower frequency of occurrence with EGN vs. VASN \\
\hline & $\begin{array}{l}1 \mathrm{SR} \\
2 \mathrm{OST}\end{array}$ & High and low & Lower frequency with MIT \\
\hline & $1 \mathrm{RCT}$ & Moderate & Lower frequency of occurrence with EGN vs. VASN \\
\hline $\begin{array}{l}\text { Reoperation due to } \\
\text { postoperative complications }\end{array}$ & $\begin{array}{l}1 \mathrm{SR} \\
4 \mathrm{OST}\end{array}$ & High and low & Lower frequency with MIT \\
\hline $\begin{array}{l}\text { Reoperation due to } \\
\text { necrosectomy }\end{array}$ & $\begin{array}{l}1 \mathrm{SR} \\
2 \mathrm{OST}\end{array}$ & High and low & Lower frequency with MIT \\
\hline $\begin{array}{l}\text { Development of diabetes } \\
\text { mellitus }\end{array}$ & $\begin{array}{l}1 \mathrm{RCT} \\
1 \mathrm{SR} \\
1 \mathrm{RCT}\end{array}$ & $\begin{array}{l}\text { Moderate } \\
\text { High } \\
\text { Moderate }\end{array}$ & $\begin{array}{l}\text { Lower frequency with EGN vs. VASN } \\
\text { Significantly lower with MIT } \\
\text { Lower frequency with EGN vs. VASN }\end{array}$ \\
\hline $\begin{array}{l}\text { Pancreatic enzyme } \\
\text { requirement }\end{array}$ & $1 \mathrm{SR}$ & High & Significantly lower with MIT \\
\hline
\end{tabular}

High quality: it is highly unlikely that future studies will change the confidence in the estimation of the effect and therefore the confidence is high. Moderate quality: is likely that future studies will change the confidence in the estimation of the effect.

Low quality: it is highly unlikely that future studies will change the confidence in the estimation of the effect.

0.12-0.88) (Cirocchi et al.); and in the RCT that compared VASN vs. EGN, lower development of diabetes mellitus was reported with EGN ( $30 \%$ vs. $22 \%$ ( $\mathrm{p}=0.33)$; $\mathrm{RR}=0.28$ (CI 95\% of $-0.17-0.63$ ) (Bakker et al.) (High and moderate quality).
Finally, for the variable "pancreatic enzyme requirement", only 1 SR (treatment studies $2 \mathrm{a}$ ) was found that reported the variable. $7.0 \%$ and $33.0 \%$ for MIT and OS respectively ( $\mathrm{p}=0.005)$; and OR of 0.005 (CI 95\% of 0.04 0.57) (Cirocchi et al.) (High quality). 


\section{DISCUSSION}

The surgical treatment of IPN remains controversial, not only in relation to the therapeutic option, but also at the moment surgery must be performed. To date numerous articles that provide information regarding the results of various more or less invasive techniques have been published unfortunately mainly as review articles and retrospective case series with less than rigorous criteria in patient selection, a situation that makes their reproduction unfeasible. Moreover, low productivity of comparative studies, the low level of evidence of what does exist and the very small population that these studies employ are all worthy of note.

As a result of the search, we only managed to obtain two SR related directly to the objective, no 1a level of evidence (in one RCT and OST are combined; and the other uses only OST as a study population); only one RCT with a study population of only 20 patients ( 10 for each branch [ $2 \mathrm{~b}$ level of evidence]); and 7 OST, all of which are retrospective (in total representing 711 patients treated with different techniques [4 level of evidence]). Therefore, the articles are also of intermediate and low methodological quality.
From the little evidence available, it can be concluded that in general terms, the MIT are associated with better results than OS in most of the analyzed variables, significantly only in the development of DM and pancreatic enzyme requirement.

The ideal form of treatment of the patient with IPN is yet to be determined. The need for studies with a better level of evidence, good methodological quality and larger populations is clear. Hopefully these can lead to establishing a cost-benefit ratio, cost effectiveness or cost utility among the different IPN treatment options, as well as to assessing the health-related quality of life associated with these procedures.

A summary of the available evidence respect to the objective of this study is shown in Table II.

\section{AGRADECIMIENTOS}

Agradecemos la colaboración de Covidien Surgical Solutions quienes nos han dado soporte para el desarrollo de esta iniciativa.

MANTEROLA, C.; URRUTIA, S. \& APODACA, F. Alternativas terapéuticas para el tratamiento de la necrosis pancreática infecciosa. Una visión general. Int. J. Morphol., 32(4):1357-1364, 2014.

RESUMEN: A pesar de los avances diagnósticos y terapéuticos, el tratamiento de la necrosis pancreática infecciosa (NPI) sigue siendo un problema complejo de resolver. El objetivo de este estudio es evaluar la eficacia de las diferentes alternativas quirúrgicas para el tratamiento del NPI. Fueron evaluados artículos publicados entre 2000 y 2013, relacionados con la efectividad de la cirugía abierta (CA) y el tratamiento mínimamente invasivo (TMI) en pacientes diagnosticados con NPI. Se PubMed, MEDLINE, The Cochrane Database of Systematic Reviews, Cochrane Central Register RCT, DARE, IBECS, SciELO, LILACS, PAHO, WHOLIS, ASERNIP-S, NIHR, HTA, Clinical Excellence, York Health Economic Consortium y Tripdatabase, en búsqueda de revisiones sistemáticas (RS), ensayos clínicos aleatorios (ECA) y estudios observacionales (EO). En estos estudios se evaluó la eficacia de la cirugía y el TMI en relación con diferentes variables, como la mortalidad, el sangrado intra-abdominal, el desarrollo de fístula enterocutánea o la perforación de víscera hueca, el desarrollo de fístula pancreática, reintervenciones por complicaciones, reintervenciones por necrosectomía, el desarrollo de diabetes mellitus y la necesidad de enzimas pancreáticas. Se consiguieron 389 artículos, de los cuales 10 cumplieron con los criterios de selección (2 RS, 1 ECA y 7 EO). Los estudios presentaron un nivel de evidencia de 2a, 2b, 3a y 4. El TMI se asocia con mejores resultados que la CA en todas las variables analizadas, pero en forma significativa sólo en el desarrollo de la diabetes mellitus y la necesidad de enzimas pancreáticas. Los artículos encontrados son pocos y heterogéneos, lo que hace difícil poder alcanzar conclusiones significativas. Se necesitan estudios con un mejor nivel de evidencia, calidad metodológica y tamaño de población estudiada para poder establecer conclusiones y recomendaciones.

PALABRAS CLAVE: "Pancreatitis, necrosante aguda/complicaciones"); "Pancreatitis, aguda necrotizante/terapia"; Necrosis pancreática infecciosa; Necrosectomía; Medicina Basada en la Evidencia; Visión general.

\section{REFERENCES}

Al Mofleh, I. A. Severe acute pancreatitis: pathogenetic aspects and prognostic factors. World J. Gastroenterol., 14(5):675-84, 2008.

Alsfasser, G.; Schwandner, F.; Pertschy, A.; Hauenstein, K.; Foitzik, T. \& Klar, E. Treatment of necrotizing pancreatitis: redefining the role of surgery. World J. Surg., 36(5):1142-7, 2012.
Bakker, O. J.; van Santvoort, H. C.; van Brunschot, S.; Geskus, R. B.; Besselink, M. G, Bollen, T. L.; van Eijck, C. H.; Fockens, P.; Hazebroek, E. J.; Nijmeijer, R. M.; Poley, J. W.; van Ramshorst, B.; Vleggaar, F .P.; Boermeester, M. A.; Gooszen, H. G.; Weusten, B. L.; Timmer, R. \& Dutch Pancreatitis Study Group. Endoscopic transgastric vs surgical necrosectomy for 
infected necrotizing pancreatitis: a randomized trial. JAMA, 307(10):1053-61, 2012.

Banks, P. A.; Freeman, M. L. \& Practice Parameters Committee of the American College of Gastroenterology. Practice guidelines in acute pancreatitis. Am. J. Gastroenterol., 101(10):2379-400, 2006.

Baril, N. B.; Ralls, P. W.; Wren, S. M.; Selby, R. R.; Radin, R.; Parekh, D.; Jabbour, N. \& Stain, S. C. Does an infected peripancreatic fluid collection or abscess mandate operation? Ann. Surg., 231(3):361-7, 2000.

Bausch, D.; Wellner, U.; Kahl, S.; Kuesters, S.; Richter-Schrag, H. J.; Utzolino, S.; Hopt, U. T.; Keck, T. \& Fischer, A. Minimally invasive operations for acute necrotizing pancreatitis: comparison of minimally invasive retroperitoneal necrosectomy with endoscopic transgastric necrosectomy. Surgery, 152(3 Suppl. 1):S128-34, 2012.

Boland, B.; Colquhoun, S.; Menon, V.; Kim, A.; Lo, S. \& Nissen, N. N. Current surgical management of infected pancreatic necrosis. Am. Surg., 76(10):1096-9, 2010.

Bruennler, T.; Langgartner, J.; Lang, S.; Wrede, C. E.; Klebl, F.; Zierhut, S.; Siebig, S.; Mandraka, F.; Rockmann, F.; Salzberger, B.; Feuerbach, S.; Schoelmerich, J. \& Hamer, O. W. Outcome of patients with acute, necrotizing pancreatitis requiring drainage-does drainage size matter? World J. Gastroenterol., 14(5):725-30, 2008.

Buter, A.; Imrie, C. W.; Carter, C. R.; Evans, S. \& McKay, C. J. Dynamic nature of early organ dysfunction determines outcome in acute pancreatitis. Br. J. Surg., 89(3):298-302, 2002.

Centre for Evidence-based Medicine at the University of Oxford. Levels of Evidence (March 2009). 2009. Available in: http:// www.cebm.net/index.aspx? $o=1025$

Cheung, M. T.; Ho, C. N.; Siu, K. W. \& Kwok, P. C. Percutaneous drainage and necrosectomy in the management of pancreatic necrosis. A. N. Z. J. Surg., 75(4):204-7, 2005.

Cirocchi, R.; Trastulli, S.; Desiderio, J.; Boselli, C.; Parisi, A.; Noya, G. \& Falconi, M. Minimally invasive necrosectomy versus conventional surgery in the treatment of infected pancreatic necrosis: a systematic review and a meta-analysis of comparative studies. Surg. Laparosc. Endosc. Percutan. Tech., 23(1):8-20, 2013.

Connor, S.; Alexakis, N.; Raraty, M. G.; Ghaneh, P.; Evans, J.; Hughes, M.; Garvey, C. J.; Sutton, R. \& Neoptolemos, J. P. Early and late complications after pancreatic necrosectomy. Surgery, 137(5):499-505, 2005.

Dillon, A. Percutaneous pancreatic necrosectomy. National Institute for Clinical Evidence (NICE), 2011. Available in: http:// www.nice.org.uk/guidance/IPG384
Donald, G.; Donahue, T.; Reber, H. A. \& Hines, O. J. The evolving management of infected pancreatic necrosis. Am. Surg., 78(10):1151-5, 2012.

Freeny, P. C.; Hauptmann, E.; Althaus, S. J.; Traverso, L. W. \& Sinanan, M. Percutaneous CT-guided catheter drainage of infected acute necrotizing pancreatitis: techniques and results. A. J. R. Am. J. Roentgenol., 170(4):969-75, 1998.

Fotoohi, M.; D'Agostino, H. B.; Wollman, B.; Chon, K.; Shahrokni, S. \& vanSonnenberg, E. Persistent pancreatocutaneous fistula after percutaneous drainage of pancreatic fluid collections: role of cause and severity of pancreatitis. Radiology, 213(2):573-8, 1999.

Gambiez, L. P.; Denimal, F. A.; Porte, H. L.; Saudemont, A.; Chambon, J. P. \& Quandalle, P. A. Retroperitoneal approach and endoscopic management of peripancreatic necrosis collections. Arch. Surg., 133(1):66-72, 1998.

Guo, Q.; Lu, H.; Hu, W. \& Zhang, Z. A retroperitoneal approach for infected pancreatic necrosis. Scand. J. Gastroenterol., 48(2):225-30, 2013.

Guyatt, G.; Gutterman, D.; Baumann, M. H.; Addrizzo-Harris, D.; Hylek, E. M.; Phillips, B.; Raskob, G.; Lewis, S. Z. \& Schünemann, H. Grading strength of recommendations and quality of evidence in clinical guidelines: report from an american college of chest physicians task force. Chest,129(1):174-81, 2006.

Hart, P. A. \& Baron, T. H. What is the role of noninvasive treatment for infected pancreatic necrosis: still an unanswered question. Gastroenterology, 144(7):1574-5, 2013.

Heinrich, S.; Schäfer, M.; Rousson, V. \& Clavien, P. A. Evidencebased treatment of acute pancreatitis: a look at established paradigms. Ann. Surg., 243(2):154-68, 2006.

Horvath, K.; Freeny, P.; Escallon, J.; Heagerty, P.; Comstock, B.; Glickerman, D. J.; Bulger, E.; Sinanan, M.; Langdale, L.; Kolokythas, O. \& Andrews, R. T. Safety and efficacy of video-assisted retroperitoneal debridement for infected pancreatic collections: a multicenter, prospective, single-arm phase 2 study. Arch. Surg., 145(9):817-25, 2010.

Jadad, A. R.; Moore, R. A.; Carroll, D.; Jenkinson, C.; Reynolds, D. J.; Gavaghan, D. J. \& McQuay, H. J. Assessing the quality of reports of randomized clinical trials: is blinding necessary? Control. Clin. Trials, 17(1):1-12, 1996.

Khanna, A. K.; Meher, S.; Prakash, S.; Tiwary, S. K.; Singh, U.; Srivastava, A. \& Dixit, V. K. Comparison of Ranson, Glasgow, MOSS, SIRS, BISAP, APACHE-II, CTSI Scores, IL-6, CRP, and Procalcitonin in Predicting Severity, Organ Failure, Pancreatic Necrosis, and Mortality in Acute Pancreatitis. H. P. B. Surg., 2013:367581, 2013. 
Lee, J. K.; Kwak, K. K.; Park, J. K.; Yoon, W. J.; Lee, S. H.; Ryu, J. K.; Kim, Y. T. \& Yoon, Y. B. The efficacy of nonsurgical treatment of infected pancreatic necrosis. Pancreas, 34(4):399-404, 2007.

Mortelé, K. J.; Girshman, J.; Szejnfeld, D.; Ashley, S. W.; Erturk, S. M.; Banks, P. A. \& Silverman, S. G. CT-guided percutaneous catheter drainage of acute necrotizing pancreatitis: clinical experience and observations in patients with sterile and infected necrosis. Am. J. Roentgenol., 192(1):110-6, 2009.

Navalho, M.; Pires, F.; Duarte, A.; Gonçalves, A.; Alexandrino, P. \& Távora, I. Percutaneous drainage of infected pancreatic fluid collections in critically ill patients: correlation with C-reactive protein values. Clin. Imaging, 30(2):114-9, 2006.

Navaneethan, U.; Vege, S. S.; Chari, S. T. \& Baron, T. H. Minimally invasive techniques in pancreatic necrosis. Pancreas, 38(8):867-75, 2009.

Raraty, M. G.; Halloran, C. M.; Dodd, S.; Ghaneh, P.; Connor, S.; Evans, J.; Sutton, R. \& Neoptolemos, J. P. Minimal access retroperitoneal pancreatic necrosectomy: improvement in morbidity and mortality with a less invasive approach. Ann. Surg., 251(5):787-93, 2010.

Roa, R. Calidad de un estudio: escala de Jadad. Atención Primaria, 2008. Available in: https://atencionprimaria.wordpress.com/ 2008/03/24/calidad-de-un-estudio-escala-de-jadad

Rocha, F. G.; Benoit, E.; Zinner, M. J.; Whang, E. E.; Banks, P. A.; Ashley, S. W. \& Mortele, K. J. Impact of radiologic intervention on mortality in necrotizing pancreatitis: the role of organ failure. Arch. Surg., 144(3):261-5, 2009.

Scottish Intercollegiate Guidelines Network (SIGN). SIGN 50: a guideline developer's' handbook. Edinburgh, SIGN, 2014. Available in: http://www.sign.ac.uk/pdf/sign50.pdf

Senthil Kumar, P.; Ravichandran, P. \& Jeswanth, S. Case matched comparison study of the necrosectomy by retroperitoneal approach with transperitoneal approach for necrotizing pancreatitis in patients with CT severity score of 7 and above. Int. J. Surg., 10(10):587-92, 2012.

Stem, J. R. \& Matthews, J. B. Pancreatic necrosectomy. Adv. Surg., 45:155-76, 2011.

Tan, J.; Tan, H.; Hu, B.; Ke, C.; Ding, X.; Chen, F.; Leng, J. \& Dong, J. Short-term outcomes from a multicenter retrospective study in China comparing laparoscopic and open surgery for the treatment of infected pancreatic necrosis. J. Laparoendosc. Adv. Surg. Tech. A, 22(1):27-33, 2012.

van Baal, M. C.; van Santvoort, H. C.; Bollen, T. L.; Bakker, O. J.; Besselink, M. G.; Gooszen, H. G. \& Dutch Pancreatitis Study Group. Systematic review of percutaneous catheter drainage as primary treatment for necrotizing pancreatitis. Br. J. Surg., 98(1):18-27, 2011. van Santvoort, H. C.; Besselink, M. G.; Bakker, O. J.; Hofker, H. S.; Boermeester, M. A.; Dejong, C. H.; van Goor, H.; Schaapherder, A. F.; van Eijck, C. H.; Bollen, T. L.; van Ramshorst, B.; Nieuwenhuijs, V. B.; Timmer, R.; Laméris, J. S.; Kruyt, P. M.; Manusama, E. R.; van der Harst, E.; van der Schelling, G. P.; Karsten, T.; Hesselink, E. J.; van Laarhoven, C. J.; Rosman, C.; Bosscha, K.; de Wit, R. J.; Houdijk, A. P.; van Leeuwen, M. S.; Buskens, E.; Gooszen, H. G. \& Dutch Pancreatitis Study Group. A step-up approach or open necrosectomy for necrotizing pancreatitis. N. Engl. J. Med., 362(16):1491-502, 2010.

Windsor, J. A. Minimally invasive pancreatic necrosectomy. $B r . J$. Surg., 94(2):132-3, 2007.

Wysocki, A. P.; McKay, C. J. \& Carter, C. R. Infected pancreatic necrosis: minimizing the cut. A. N. Z. J. Surg., 80(1-2):58-70, 2010.

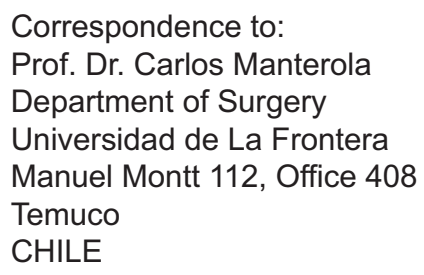

Email: carlos.manterola@ufrontera.cl

Received: 11-07-2014

Accepted: 04-10-2014 